
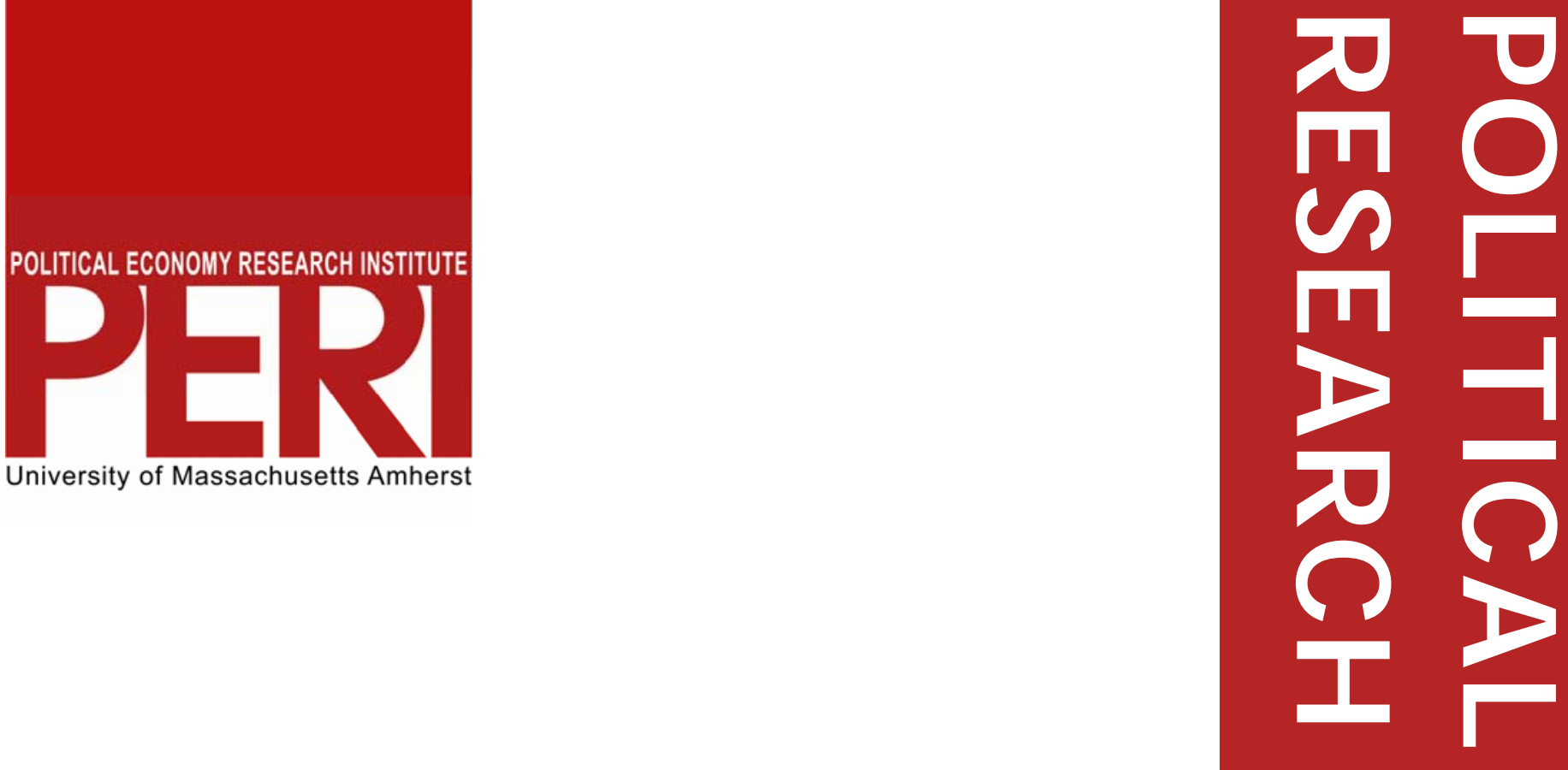

Regulating Wall Street:

Exploring the Political Economy of the Possible

\author{
Gerald Epstein and Robert Pollin
}

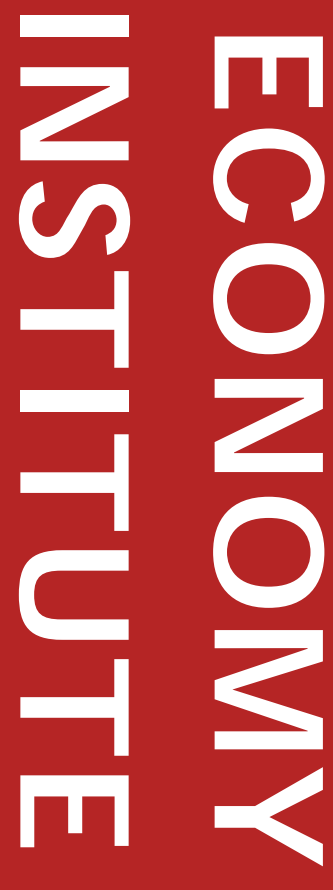

Gordon Hall

418 North Pleasant Street

Amherst, MA 01002

March 2011

Phone: 413.545 .6355

Fax: 413.577 .0261

peri@econs.umass.edu www.umass. edu/ peri/

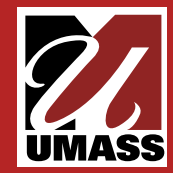




\title{
Regulating Wall Street: Exploring the Political Economy of the Possible
}

\author{
Gerald Epstein and Robert Pollin \\ Department of Economics and \\ Political Economy Research Institute (PERI) \\ University of Massachusetts-Amherst \\ gepstein@econs.umass.edu; pollin@econs.umass.edu
}

March 2011

Chapter forthcoming in Philip Arestis ed., Microeconomics, Macroeconomics and Economic Policy, London: Palgrave Macmillan, 2011

This volume is a festschrift in honor of Professor Malcolm Sawyer 


\title{
REGULATING WALL STREET: EXPLORING THE POLITICAL ECONOMY OF THE POSSIBLE
}

\author{
Gerald Epstein and Robert Pollin \\ March 2011
}

JEL Codes: G28, E44

\begin{abstract}
The Dodd-Frank Wall Street Reform and Consumer Protection Act in July 2010 is the most ambitious measure aimed at regulating U.S. financial markets since the Glass-Steagall Act was implemented in the midst of the 1930s Depression. However, it remains an open question as to whether Dodd-Frank is capable of controlling the wide variety of hyper-speculative practices that produced the near total global financial collapse of 2008-09. This is because the legislation mainly lays out a broad framework for a new financial regulatory system. It leaves the details of implementation to ten different regulatory bodies in the U.S. The lack of specificity in setting down new financial regulations was widely viewed as a victory for Wall Street, and equally, a defeat for proponents of a strong new regulatory system.

It is clear that Wall Street is moving into the phase of regulatory rulemaking with a strong hand. However, it is still the case that dominance by Wall Street in implementing Dodd-Frank is not a foregone conclusion. Rather, Dodd-Frank remains a contested terrain-supporters of financial regulation can still achieve significant victories within the regulatory framework created by Dodd-Frank. The focus of this paper is to explore three central areas of Dodd-Frank where we think effective regulations can be established. These are 1) proprietary trading by banks and other financial institutions, 2) oversight of credit rating agencies such as Moody's and Standard \& Poors' and 3) the markets for commodities futures derivative contracts. In each of these areas, we address the question: under what conditions are some of the basic features of Dodd-Frank capable of succeeding in controlling hyper-speculation and promoting financial stability?
\end{abstract}


"The world can be and has been changed by those for whom the ideal and real are dynamically contiguous."

\section{—William James}

\section{Introduction}

U.S. President Barack Obama signed into law the Dodd-Frank Wall Street Reform and Consumer Protection Act in July 2010. Dodd-Frank is the most ambitious measure aimed at regulating U.S. financial markets since the Glass-Steagall Act was implemented in the midst of the 1930s Depression. However, it remains an open question as to whether Dodd-Frank is capable of controlling the wide variety of hyper-speculative practices that produced the near total global financial collapse of 2008-09, which in turn brought the global economy to its knees, with the Great Recession.

Of course, Dodd-Frank would not have been necessary in the first place, and the Great Recession itself would not have occurred, had U.S. politicians-Democrats and Republicans alike-not chosen to dismantle the Glass-Steagall system step-by-step, beginning in the 1970s. The basic argument in behalf of deregulation that began emerging in the 1970s, advanced by an overwhelming majority of mainstream economists, was that Glass-Steagall was designed in reaction to the 1930s Depression and was no longer appropriate under contemporary conditions. This chorus of politicians and economists was correct that the financial system has become infinitely more complex since the 1930s and that Glass-Steagall had become outmoded. But it never followed that financial markets should operate unregulated, as opposed to renovating the regulatory system to address the most recent developments.

Dodd-Frank is a massive piece of legislation, 875 pages in length, covering a wide range of issues. These include coordinating the management of the Federal Reserve and other financial regulatory agencies around issues of systemic risk; bringing hedge funds and derivative markets under regulatory supervision; creating effective prohibitions on proprietary trading by investment banks; establishing new oversight over public credit rating agencies; and creating a consumer financial protection bureau.

It is inevitably difficult to fully anticipate the effects over time of any major piece of economic legislation, since economic conditions and institutions are always evolving, including as a result of the regulatory environment. But such challenges are especially large in trying to 
forecast the likely impacts of Dodd-Frank. This is because the legislation itself, despite its enormous length, mainly lays out a broad framework for a new financial regulatory system. It leaves the details of implementation to ten different regulatory bodies in the U.S. These include the U.S. Treasury, Federal Reserve, Securities and Exchange Commission, and Commodities Futures Trading Commission, in addition to requesting action as well from overseas agencies such as the Basil Committee on Banking Reform. Dodd-Frank calls on these agencies to set down 243 separate rules, and to undertake 67 separate studies to inform the rulemaking process. The final set of rules under Dodd-Frank are designed to be implemented only over a number of years, up to 12 years in some areas.

The lack of specificity in setting down new financial regulations was widely viewed as a victory for Wall Street, and equally, a defeat for proponents of a strong new regulatory system. This is because both Wall Street lobbyists as well as advocates of strong regulation anticipate that the lobbyists will be able to dominate the process of detailed rulemaking to a greater extent than they managed in establishing Dodd-Frank's broad guidelines during Congressional deliberations.

It is clear that Wall Street is moving into the phase of regulatory rulemaking with a strong hand. First, the major Wall Street firms have huge budgets at their disposal to intervene at will during the process of detailed rule-setting. By contrast, the supporters of strong regulations operate with budgets that are miniscule by comparison. The Wall Street firms also have a direct and intense level of self-interest tied up in the details of specific rulings. For reformers, the level of direct connection, and thus direct interest, is likely to be far less on any given detailed matter. Finally, there is the matter of pure regulatory capture. Regulators understand that they can burnish their future private sector career opportunities if they are solicitous to the concerns of Wall Street while still employed on the public payroll.

These are all unavoidable realities. However, it is still the case-and indeed the central premise of this paper - that dominance by Wall Street in implementing Dodd-Frank is not a foregone conclusion. Rather, Dodd-Frank remains a contested terrain-supporters of financial regulation can still achieve significant victories within the regulatory framework created by Dodd-Frank.

The political ammunition in behalf of a strong regulatory system begins with a simple fact. This is the overwhelming evidence provided by the financial meltdown itself that weakly regulated financial markets will produce economic disasters. The final version of Dodd-Frank that was passed into law testifies to the force of this factor. Despite the weaknesses and ambiguities included the final law, many features of measure did become stronger through the drafting process, as lobbying efforts by Americans for Financial Reform and other citizens' groups effectively exerted influence over many areas of the debate. Americans for Financial Reform (AFR) describes itself as follows on its website: "We are a coalition of more than 250 
national, state and local groups who have come together to reform the financial industry. Members of our coalition include consumer, civil rights, investor, retiree, community, labor, religious and business groups as well as Nobel prize winning economists." The voices of the people did end up mattering in the debate.

But there is a second crucial factor as well. This is, it is not necessary for the supporters of effective regulations to win victories on all 243 rules that need to be decided, or to have their positions incorporated into all 67 studies mandated by the legislation. Rather, a great deal can be achieved through achieving effective rules in a few key areas within the full expanse of DoddFrank.

The focus of this paper is to explore three central areas of Dodd-Frank where we think effective regulations can be established. These are 1) proprietary trading by banks and other financial institutions, 2) oversight of credit rating agencies such as Moody's and Standard \& Poors' and 3) the markets for commodities futures derivative contracts. In each of these areas, we address the question: under what conditions are some of the basic features of Dodd-Frank capable of succeeding in controlling hyper-speculation and promoting financial stability?

In pursuing these questions, we are guided by the formidable body of research in the areas of macroeconomics, finance and policymaking by Professor Malcolm Sawyer. Over the course of nearly 40 years, beginning with such important early works as Macroeconomics in Question: The Keynesian-Monetarist Orthodoxies and the Kaleckian Alternative (1982), Prof. Sawyer has made major contributions to developing a Post Keynesian heterodox tradition. Professor Sawyer's work has been crucial in enabling those of us willing to learn from him to both understand the severe deficiencies of orthodox macroeconomics as well as advance a positive agenda for explaining the world and changing it for the better. Indeed, among Post Keynesian macroeconomists, Sawyer's contributions have been unique through their insistence on attacking fundamental questions rigorously at both the levels of theory and policy.

By taking seriously the analytic questions connected to the specifics of designing economic policies, Sawyer has also been able to bring remarkable depth to exploring the most pressing questions in macroeconomics today. This quality of Sawyer's work is dramatically evident in, for example, his 2005 survey paper with Philip Arestis "Financial Liberalization and the FinanceGrowth Nexus: What Have We Learned?” Reading this paper five years after it was publishedthat is, three years prior to the global financial collapse and Great Recession-Sawyer and Arestis could not have been more prescient in exposing as fraudulent both the theoretical and empirical cases for financial deregulation. Sawyer and Arestis wrote this paper at a time when the overwhelming majority of mainstream economists still clung fiercely to both their theoretical and empirical claims in behalf of financial deregulation. Yet Sawyer and Arestis concluded their paper as follows: 
It is clear from this excursion in the literature that no convincing evidence has been provided in support of the propositions of the financial liberalization hypothesis.

On the contrary, the available evidence can be interpreted as indicating that the theoretical propositions of the thesis are at best weak, and as such they ought to be abandoned. (p. 33).

Our aim here is to work within this analytic tradition advanced by Malcolm Sawyer. The next three sections of the paper consider, respectively, questions regarding the regulations of proprietary trading and related matters; the credit rating agencies; and the commodities futures derivative market. The paper then concludes with some brief general observations.

\section{Prohibitions on Proprietary Trading}

One of the most important provisions of Dodd-Frank is the so-called "Volcker rule." This is actually not one rule, but a serious of measures, which were strongly supported by former Federal Reserve Chair Paul Volcker, to prevent propriety trading and related highly risky and destabilizing activities by banks. The Volcker rule aims to also impose limits and large capital charges on propriety trades by non-bank financial intermediaries, such as hedge funds and private equity firms.

Propriety trading and related activities by large banks and other major financial firms was a primary cause of the financial bubble as well as the collapse of the bubble and near total global meltdown in 2008-09. This was due to the fact that proprietary trades by the banks was a key force in sustaining upward pressure on security prices, thereby feeding the bubble. The banks ran large trading books - inventories of securities that they themselves own-ostensibly to operate as market makers only for their clients. But maintaining large trading books enabled them to operate with inside information on their clients' trading patterns to stay ahead of market movements, i.e. to "front run."

In addition, these activities were funded mainly with short-term borrowing and backed up with questionable collateral. The banks were able to operate in this way because the accounting standards for such activities were weak, enabling the banks to operate free of public scrutiny. The proprietary trades were also closely intertwined with hedge funds, insurance companies and private equity funds, often involving credit default swaps and other opaque financial instruments. For example, a large investment bank, such as Goldman Sachs, could sell bundles of mortgagebacked securities to private investors, and these clients could purchase insurance on these securities, in the form of credit default swaps from, say, AIG. All of these transactions could then be debt-financed to an unlimited degree, raising the level of risk exposure to all the parties to each level of transaction-i.e. to the private investors, Goldman Sachs and AIG. It was 
precisely such series of interconnections, formed on the basis of high levels of leveraging, that fueled the credit market bubble, which in turn led to the crash. ${ }^{1}$

It is difficult to know for certain how large were the banks’ proprietary trading activities. Within days of the announcement of the proposed Volcker rules to limit proprietary trading, the business press reported that proprietary trades were actually small parts of the major banks' overall operations. For example, the Wall Street Journal reported on 1/21/10 that proprietary trades made up about 10 percent of Goldman Sachs revenue, 5 percent for Citibank, less than 5 percent for Morgan Stanley and less than 1 percent for Bank of America and J.P. Morgan. ${ }^{2}$

However, there is strong evidence that these figures are much too low. This is because it is difficult to separate out propriety trading from trading for clients and market making. Working with the available data, Crotty, Epstein and Levina (2010) found that as of mid-2008, large banks had lost roughly $\$ 230$ billion-about one-third of their value as of the 2006 market peak-on their propriety holdings of what were presumed to have been low-risk AAA-rated assets. The banks were holding little to no reserve funds to support these assets in the event of a market downturn. Regulators thought that these were simply inventories of assets held to facilitate client trading. But Crotty et al. show that this proprietary portfolio constituted roughly $1 / 3$ of the total trading portfolio, including assets managed for clients and those available for the banks' use as market makers. Crotty et al. further show that as of 2006, prior to the crisis, propriety trading accounted for a very high proportion total net revenue for the major investment banks-i.e. 64 percent or more for Goldman Sachs and 43 percent for Morgan Stanley.

\subsection{How Dodd-Frank Could Control Proprietary Trading}

Dodd-Frank includes four major features intended to dramatically reduce the risks associated with proprietary trading by banks as well as the highly risky interconnections between banks and other intermediaries, such as hedge funds.

First, the legislation includes a blanket prohibition against banks engaging in transactions involving material conflicts of interest or highly risky trading activities. The precise language in Dodd-Frank reads as follows:

"No transaction, class of transactions, or activity may be deemed...permitted...if it (i) would involve or result in a material conflict of interest...(ii) would result, directly or indirectly in material exposure by the banking entity to high-risk assets or high-risk trading strategies...(iii) would pose a threat to the safety and

\footnotetext{
${ }^{1}$ One excellent and relatively brief discussion within an already extensive literature on these issues is Jarsulic (2010).

${ }^{2}$ This Wall Street Journal article and related references are presented in Crotty, Epstein and Levina (2010).
} 
soundness of such banking entity; or (iv) would pose a threat to the financial stability of the United States.” (Dodd-Frank Act, Section 619(2)((A)(i - iv).

In principle, these are very strong regulatory standards. However, to implement these standards in practice, regulators will need to establish clear definitions for the concepts of "material conflict of interest," and "high-risk trading strategy." Without clear and workable definitions of these terms, these provisions of Dodd-Frank cannot possibly succeed in achieving their intended purpose.

In addition to these outright prohibitions, Dodd-Frank also establishes that regulators impose capital requirements or other quantitative limits on trading, such as margin requirements, on banks or significant non-bank financial firms engaged in risky trading activities. Moreover, the Volcker rule regulations also restrict interactions between banks and non-bank affiliates that are engaged in high-risk trading and investing.

Capital requirements entail that traders maintain a minimal investment of their own cash relative to the overall size of their level of asset holdings, while margin requirements require traders to use their own cash reserves, in addition to borrowed funds, to make new asset purchases. There are two interrelated purposes to both capital and margin requirements. The first is to discourage excessive trading by limiting the capacity of traders to finance their trades almost entirely with borrowed funds. The second is to force the banks to put a significant amount of their own money at risk when undertaking new asset purchases, i.e. to "put skin in the game.”

Here again, in principle, these measures can be highly effective at reducing excessively risky practices by banks and other intermediaries. But whether they will succeed in practice will depend on the specific decisions undertaken by the relevant regulatory agencies. As the law in this section is written, the regulatory agencies have full discretion in establishing whether and to what extent "additional capital and quantitative limitations are appropriate to protect the safety and soundness of banking entities engaged in such activities.” For the regulatory agencies to make these decisions will require clarity as to the processes which create fragile financial structures and how to apply the regulatory tools most effectively to prevent excessive risk-taking and fragility.

More generally, even while Dodd-Frank establishes strong general principles for regulation, it also allows for exemptions from regulations as well as various ambiguities that could be readily exploited by the banks. For example, Dodd-Frank allows banks to own some shares in hedge and private equity funds. This could make it easier for banks to hide proprietary trading in the deals executed through hedge funds. Dodd-Frank also allows for proprietary trading as long as such activities support "market-making activities" and "risk-mitigating 
hedging activities,” (from Section 619(d)). It will be difficult for regulators to distinguish these activities from front-running proprietary trading by the banks and other activities entailing conflicts of interest. Such exemptions from the strong regulatory principles articulated within Dodd-Frank are exactly what Stiglitz was referring to in writing that "unfortunately, a key part of the legislative strategy of the banks was to get exemptions so that the force of any regulation passed would be greatly attenuated. The result is a Swiss cheese bill-seemingly strong but with large holes," (2010, p. 335).

In short, Dodd-Frank does provide sufficiently strong regulatory tools for controlling proprietary trading. The real question is whether these tools will be permitted to operate effectively, or whether, alternatively, the Swiss cheese features of the law become predominant over time.

\section{Public and Private Credit Rating Agencies}

The major private credit rating agencies-Moody’s, Standard \& Poors, and Fitch-were significant contributors in creating the financial bubble and subsequent financial crash of 200809. The rating agencies were supposed to be in the business of providing financial markets with objective and accurate appraisals as to the risks associated with purchasing any given financial instrument. Instead, they consistently delivered overly optimistic assessments of assets that either carried high, or at the very least, highly uncertain risks.

Moreover, the reason these agencies consistently understated risks was not simply that they were relying on economic theories that underplay the role of systemic risk in guiding their appraisals, though this was a contributing factor. The more significant influence was market incentives themselves, which pushed the agencies toward providing overly favorable appraisals. That is, giving favorable risk appraisals was good for the rating agencies' own bottom line, and the rating agencies responded in the expected way to these available opportunities.

The Dodd-Frank Act contains a provision addressing this question, written by Senator $\mathrm{Al}$ Franken, based on a proposal from James Lardner of the Demos Institute (2009). The Franken provision calls on the SEC to create a ratings oversight board with investor representatives in the majority. This board will choose a rating agency to conduct the initial evaluation of each new set of structured finance products. Securities issuers would not be allowed to participate in the assignment of raters, and the assignments would be based on an evaluation of accuracy of ratings over time. In addition, under this approach, the SEC will have an Office of Credit Ratings with the authority to write rules and levy fines. Investors will now be able to recover damages in private anti-fraud actions brought against rating agencies for gross negligence in the rating. 
Rating agencies are also required to establish their ratings on a consistent basis for corporate bonds, municipal bonds, and structured finance products and instruments.

The ratings agencies and banks fought hard to weaken this Franken amendment. The final outcome was that Dodd-Frank requires the SEC to undertake a two-year study, and on the basis of the study to either implement the Franken proposal or an alternative that eliminates the conflict of interest problem with rating agencies. Given that Dodd-Frank remains open in terms of adopting either the Franken proposal or an alternative, we describe here what we believe would be the most effective approach. This is to create a public credit rating agency that operates free of the same perverse incentive system that distorts the work of private agencies. We then compare the strengths of this proposal relative to the Franken approach.

\subsection{Public Credit Agency as Corrective ${ }^{3}$}

The fundamental contribution of a public credit rating agency would be to offer a counterforce to the perverse incentive system facing private agencies. It is true that providing accurate risk appraisals has become increasingly challenging as securitized markets have deepened. There may well be situations in which the staff of the public agency concludes that an instrument is too complex to provide an accurate risk appraisal. In such situations, it would be the obligation of the public agency to be open with such an assessment - that is, to assess an instrument as "not ratable." Financial market participants could then decide the degree to which they might wish to take a gamble with such an instrument.

The public credit rating agency operating in this way would dramatically change the incentives for the private rating agencies as well as the broader array of financial market participants. It would weaken the biases in favor of greater risk and complexity, and move the financial system to operate with a higher level of transparency. The private agencies would be free to continue operating as they wish. But when their appraisals differ significantly from those provided by the public agency, the private agencies would be forced to explain the basis for their divergent assessments.

Market participants would thus be free to evaluate the full range of information and assessments available to them, from the public agency, the private agencies, and elsewhere. It is useful to recall that in the 1980s, Michael Milken of the now defunct firm Drexel Burnham Lambert created the "junk bond" market precisely by insisting that the traditional rating agencies were overly cautious in their appraisals of corporate bonds. Market participants could make comparable assessments on their own with respect to the appraisals of the public rating agencies.

\footnotetext{
${ }^{3}$ The following discussion draws on the more fully developed proposal in Diomande, Heintz, and Pollin (2009)
} 


\subsection{How the Agency Could Operate}

We propose that all private businesses issuing securities that are to be traded publicly in U.S. financial markets would be required to seek a rating by the public agency before any trading could be conducted legally. The security could be legally traded after the public agency had issued its appraisal, even if the appraisal ended up being “not ratable.”

The new agency could be organized to operate through procedures that borrow from existing regulatory agencies in the United States, including the Food and Drug Administration as well as the SEC. Just as the FDA assesses health risks associated with new pharmaceuticals before the drugs can be marketed, the public ratings agency would assess the riskiness of financial assets before the securities could be publicly traded. Unlike the FDA, the public rating agency would not have the authority to prevent securities from being marketed, but only to offer their independent risk assessment. Similar to the SEC, which is financed largely through a lowlevel securities transactions tax and registration fees, the public ratings agency could be financed by cost-recovery fees.

The staff of the public agency would be compensated as high-level civil servants. They would receive no benefits as such from providing either favorable or unfavorable ratings. Indeed, a compensation system could be established whereby the professional staff is evaluated on the basis how well their risk assessments of given assets end up comporting with the market performance of these assets over time. Safeguards would be put in place to dismiss any professional staff members who have conflicts of interest that could compromise the integrity of their ratings.

\subsection{Comparing a Public Rating Agency with the Franken Proposal}

The key difference between the two approaches is that with the public rating agency, a new independent source of market information will have been established. The explicit and only mandate of this agency will be to serve the public interest in conducting ratings. Under the Franken proposal, the private agencies would still be the only entities which are operating with adequate staffing levels to conduct appraisals of new financial market products. The SEC would be contracting with the private agencies on an individual basis to produce appraisals under the Franken proposal. However, the private agencies would still be primarily in the business of providing ratings for private-sector firms that hire the agencies to conduct appraisals. The profits of the private agencies would therefore still be coming mainly from the major Wall Street firms, and this central fact will not be lost on the private agencies. And even when a given agency is providing a rating under contract with the SEC as opposed to a private Wall Street firm-e.g. Moody's has been hired by the SEC to evaluate a new credit default swap being issued by 
AIG - the market will have to be clear that this particular rating by Moody's was based on a different contractual arrangement than its normal operating procedure.

It is true that, under the Franken proposal, the private rating agencies will become more vulnerable legally should they be found guilty of "gross negligence" in producing excessively optimistic ratings. But legal correctives of this sort can only be applied years after the compromised ratings have been issued. In the meantime, the private ratings agencies could have provided their seal of approval to a new financial bubble. Moreover, even in attempting to apply this legal remedy years after a bubble has inflated and collapsed, it will be very difficult to prove "gross negligence" in a court of law. This is because the rating agencies could accurately claim that their ratings were only reflecting the views of the vast majority of other market analysts at that time. On this point, it is important to underscore that a financial bubble expands precisely because lots of people are receiving huge financial rewards through rapidly rising asset values. These people naturally want the bubble to continue for as long as possible. Former Federal Reserve Chair Alan Greenspan himself used the evocative terms "irrational exuberance" and "infectious greed" to describe the self-feeding momentum that drives financial bubbles.

Given these incentives among private parties in financial markets, what becomes clear is the importance of creating at least one rating agency operating unambiguously in the public interest. This agency, moreover, needs to be held accountable contemporaneously, indeed on a day-to-day basis, just as financial firms issue new securities on a day-to-day basis. Such an arrangement is not possible under the Franken proposal. As such, creating a public agency with such a straightforward mission would actually be easier to administer than the Franken proposal. It would entail far less ambiguity in terms of the source of any given rating, since the public would know that the rating came from the public agency, not a private agency operating on a part-time basis under an SEC contract. Creating a public agency would also mean far fewer opportunities for distorting the intentions of the regulations through legal challenges and manipulation.

\section{Commodities Futures Market Speculation}

Financial deregulation, particularly from the late 1990s onward, led to other economic malignancies in addition to being the primary cause of the financial bubble and subsequent financial crash and Great Recession of 2008-09. Dodd-Frank offers an opportunity to address these matters as well. 
First on this list of additional malignancies was that the commodities futures derivative markets-including the markets for futures contracts in energy and food commodities_-became new venues for Wall Street hyper-speculation. ${ }^{4}$

Futures markets for food, oil and other commodities have long been used by farmers and others to maintain stability in their business operations and plan for the future. For example, under a "plain vanilla” wheat futures contract, a farmer could spend $\$ 50,000$ planting her crop now, and agree now with a commodities futures trader to sell the crop at a fixed price when the crop is harvested. But such simple agreements became increasingly overwhelmed by big-time market speculators in 2000 when the markets were deregulated, along with the rest of the U.S. financial system. Deregulation produced severe swings in the global prices of food and oil. The most severely impacted victims of commodity price volatility are people in developing countries, where it is common for families to spend 50 percent or more of their total income on food. The United Nations found that sharp price increases in 2008-a 40 percent average increase across a range of different food items_-led to malnourishment for 130 million additional people. ${ }^{5}$

Provisions of Dodd-Frank offer the opportunity for meaningful control of these markets. Moreover, the regulations that will apply to the commodities futures market will also extend to the trading of derivatives instruments more generally. Our discussion here will focus only on commodities futures derivatives.

Dodd Frank establishes four basic tools for regulating commodity futures markets: an outright prohibition of agricultural swap markets; capital requirements for organizers of all derivative exchanges, along with margin requirements and position limits for traders on these exchanges. In addition, Dodd-Frank stipulates that most trading be conducted on exchanges as opposed to unregulated over-the-counter (OTC) markets. If implemented effectively, these tools can provide a viable framework for promoting stability in derivative markets.

We have already discussed above how capital and margin requirements can be used effectively to dampen excessively risky arrangements between traditional banks and shadow banks. This same tool can also be effective in dampening speculation on commodities futures markets. We therefore focus here on position limits and on the issue of granting exemptions to the regulations, which are permitted in principle under Dodd-Frank.

\subsection{Position Limits}

Dodd-Frank requires the Commodities Futures Trading Commission (CFTC) to establish limits on contracts for physical commodities. The purpose of position limits is to prevent large speculative traders from exercising excessive market power. That is, large traders

\footnotetext{
${ }^{4}$ Ghosh (2010) offers an excellent overview of this development.

${ }^{5}$ This figure was cited by Sheeran (2008), Executive Director of the UN World Food Programme.
} 
can control the supply side of derivative markets by taking major positions, either on the short or long side of the markets. Once they control supply, they can then also exert power in setting spot market prices.

A useful starting point for analyzing where to set the position limits would be with the experiences in food commodities futures during the huge price run up from 2006-08. Table 1 below shows the position limits at that time for corn, soybeans and wheat, along with the average position size for three types of long traders, as defined by the CFTC, i.e, commercial, noncommercial, and index traders. "Commercial traders" are producers or consumers of commodities, such as farmers, oil companies or airlines who wish to hedge against future market risks; "non-commercial traders" are brokerage houses or hedge funds that will sell futures or swap contracts to commercial traders; and "index traders" are those holding positions in an basket—i.e. index fund — of commodities. They trade based on the movements of this index fund relative to movements in other asset markets, such as stocks, bonds, and real estate. The index traders are generally large hedge funds or equity holding companies.

To begin with, the figures in Table 1 below show clearly that the position limits that operated in 2006-08 were relevant only for index traders. The average position sizes for both commercial and non-commercial traders were far below the stipulated limits.

Table 1. Futures and Options Market Long Positions by Trader Group January 2006 - December 2008

\begin{tabular}{|l|r|r|r|r|}
\hline & $\begin{array}{l}\text { Position Limit } \\
\text { (\# of contracts) }\end{array}$ & \multicolumn{3}{|c|}{ Average Position Size (\# of contracts) } \\
\hline & 22,000 & $\begin{array}{l}\text { Commercial } \\
\text { traders }\end{array}$ & $\begin{array}{l}\text { Non-commercial } \\
\text { traders }\end{array}$ & Index traders \\
\hline Corn & 10,000 & 1,499, & 1,134 & 16,260 \\
\hline Soybeans & 6,500 & 1,052 & 590 & 6,500 \\
\hline Wheat & 964 & 553 & 8,326 \\
\hline
\end{tabular}

Source: UNCTAD Trade and Development Report 2009, p. 64.

In terms of the index traders, with corn, the position limit was 22,000 contracts, a figure well above the average position of index traders of 16,260. These figures suggest that the stipulated position limit was not likely binding on the behavior of most index traders, though there may have been some cases of very large index traders holding positions well above the average. A similar story holds with soybeans, where the position limit was 10,000 contracts, while the average position size for index traders was 6,024. However, the situation is different with wheat. The position limit there was 6,500 , but the average index trader held 8,326 
contracts. These figures for wheat futures suggest two things: 1) the position limits were set at a level that would have been binding for a significant share of index traders; but 2) the limits were not binding in fact, since the average trader held nearly 30 percent more contracts than the position limits permitted. Obviously, large index traders in wheat futures were granted exemptions from the stipulated position limits (UNCTAD 2009, p. 65)

The contrasting experiences with the corn, soybeans and wheat markets over 2006-08 could thus shed light on how to effectively use the tool of position limits in preventing index traders from exercising excessive market power. One approach would be to set position limits based on the actual position levels of commercial traders, as opposed to index traders, assuming that the distinctions between these can be clearly established through the data. For example, one could set the position limits as one standard deviation greater than the median position levels for commercial traders.

However, the most serious problem here is that as trading practices have become more complex, it becomes increasingly difficult to clearly establish distinctions between "commercial" and "index" traders, certainly for purposes of writing regulations that could hold firm against legal challenges. This point was illustrated well in a paper by Silber, "On the Nature of Trading: Do Speculators Leave Footprints?” This paper was published in 2003, years before index trading exploded in commodities futures markets. Silber describes how two types of traders, what he terms "market-makers" and "speculators" establish their positions and manage their risk exposure. Market-makers are customer-based traders, corresponding closely to what we have termed "commercial traders," who earn money on the bid/ask spread without speculating on future prices. His category of "speculators," corresponding to the category of "index traders," are those who earn money trying to anticipate the direction of future price movements. The key relevant point here is that Silber's discussion makes clear that balance sheets are insufficient to determine whether a trader is a market-maker or a speculator. This means that speculators can readily engage in activities that, a least through examining their balance sheet, would make them appear to be market-makers.

Given this difficulty in distinguishing categories of traders in commodities futures markets, the simplest solution for establishing position limits is to develop an approach that does not rely on making such distinctions. In fact, this can be accomplished readily, by generalizing from the idea of defining position limits relative to the median trading levels of commercial traders. That is, we can simply set limits relative to the median trading level of all traders in the market. The total number of index traders is small relative to other traders, even though their average positions are much larger. As such, to set position limits relative to the median for the overall market will accomplish the same outcome as attempting to set limits only after having distinguished commercial from index traders. In addition, to prevent the position limits from 
moving excessively based on possible large swings in the levels of market activity, this approach could be adjusted by, for example, defining the median position as a moving average of actual positions over, say, a three year period.

\subsection{Scope of Coverage and Exemptions}

The expansion in regulatory coverage through Dodd-Frank for derivative markets, including the commodities futures markets, includes some potentially significant exemptions. The first is the commercial end-user exemption to clearing. This provides exemptions to any swap counterparty that is 1) not a financial entity; and 2) is using the swap to hedge or mitigate commercial risk. But even more generally, the CFTC may grant any exemptions it deems appropriate from the prescribed position limits.

The aim in offering such exemptions is to prevent the Dodd-Frank regulations from imposing excessive burdens on derivative market participants who are legitimate hedgers, and are thereby not contributing to destabilizing the markets. This may be a desirable goal in principle. But in practice, it will be difficult for the CFTC to sort out which market participants truly merit exemptions by the standards established. As such, the effectiveness of the entire regulatory framework around derivative markets will hinge on the CFTC proceeding with great caution in offering exemptions. The only way to insure that the Dodd-Frank regulations are implemented effectively is to allow no exemptions at all.

\subsection{How to Prevent Regulatory Arbitrage}

For traders to shift the physical or, more importantly, legal venue of trading activity to minimize regulations - i.e. to engage in regulatory arbitrage-is a real concern with the DoddFrank derivative regulations, but it hardly a new problem. Indeed, a parallel situation arose with U.S. derivative regulations beginning with the so-called "Enron loophole" in 2000. The Enron loophole exempted over-the-counter energy trading undertaken on electronic exchanges from CFTC oversight and regulation. Enron quickly seized this market opportunity to create an artificial electricity shortage in California in 2000-01, which led to multiple blackouts and a state of emergency, and, finally, the collapse of Enron itself and its once big-five accounting firm, Arthur Andersen. Nevertheless, following Enron's example, the big market players subsequently took advantage of similar major loopholes - the "London loophole" for nominally foreign market trading and the "Swap dealer loopholes," which permitted all swap trading to move into OTC markets. The overall effect was to enable the OTC markets to flourish alongside the regulated markets (UNTCAD, pp. 76-77). 
There are no definitive solutions to regulatory arbitrage, which means, to begin with, regulators must remain fully conscious of the problem and vigilant in pursuing solutions that maintain the integrity of the regulatory system. The most effective starting point would be for all major trading platforms to agree to implement complimentary regulations. However, even with serious international efforts at regulatory harmonization, the whole point with traders intent on avoiding regulation is to find trading platforms anywhere that will enable them to operate as they wish, regardless of whether there is a major market already established at that setting.

As such, the most reliable approach for the U.S. market would be to establish a straightforward rule, whereby trading of derivative instruments would need to be conducted within the standards of the U.S. regulatory system in order for such transactions to have legal status in the United States. If such a rule were established, we would envision few instances in which derivative traders would be willing to forego the protections of the U.S. legal system simply to avoid regulations.

\section{Summary and Conclusions}

Financial deregulation in the United States - which begin in the 1970s but became formally codified with the repeal of the Glass-Stegall Act in 1999-has proven disastrous to human well-being both within the U.S. and globally, just as Post Keynesians and allied heterodox economists had long admonished. For more than a generation, Malcolm Sawyer has been a leading voice making the case against neoliberal economic policies generally and financial deregulation specifically.

But how do we move forward, digging out of the wreckage created by financial deregulation and building an effective new regulatory framework? Most progressives in the United States regard the new Dodd-Frank regulatory law as offering little promise, because the "Swiss cheese" features of the law offer Wall Street lobbyists a multitude of opportunities to water down the regulations to their liking, operating in conjunction with sympathetic regulators at the major government agencies. This remains a serious possibility, but, as we try to show, not a foregone conclusion.

Rather, we try to show how Dodd-Frank can be used as a framework for building effective regulations. We concentrate on three crucial areas in this paper-proprietary trading, the credit rating agencies, and the commodities futures derivative markets. Similar possibilities exist in other areas as well. In our three chosen areas, we argue that some fairly straightforward regulatory tools can accomplish a great deal. These include capital and margin requirements, position limits, a public credit rating agency, and, most generally, enforcing the principles set 
down within Dodd-Frank, such as banks being prohibited from engaging in activities that "would pose a threat to the financial stability of the United States.”

We are not so naïve as to assume that because these regulatory standards will be enforced effectively simply because they are written down on paper within Dodd-Frank. But the fact that they are indeed written down on paper does offer real opportunities for serious political engagement and positive outcomes. Capturing these opportunities will require insightful economic analysis in the heterodox economic tradition in combination with effective political mobilizations, recalling, as we proceed, the William James epigram which begins this paper, that "the world can and has been changed by those for whom the ideal and real are dynamically contiguous.”

\section{References}

Arestis, P. and M. Sawyer (2005) "Financial Liberalization and the Finance-Growth Nexus: What Have We Learned?” in Arestis and Sawyer eds., Financial Liberalization: Beyond Orthodox Concerns, London: Palgrave Macmillan, pp. 1-43.

Crotty, J., G. Epstein, and I. Levina (2010), "Proprietary Trading is a Bigger Deal than Many Bankers and Pundits Claim,” SAFER Policy Brief \#20, 2/18/10, Political Economy Research Institute, http://www.peri.umass.edu/fileadmin/pdf/other_publication_types/SAFERbriefs/SAFER _issue_brief20.pdf

Diomande, M. A., J. Heintz, and R. Pollin (2009) "Why U.S. Financial Markets Need a Public Credit Rating Agency,” The Economists’ Voice, June 2009, http://www.bepress.com/cgi/viewcontent.cgi?article=1507\&context=ev

Ghosh, J. (2010) “Unnatural Coupling: Food and Global Finance,” Journal of Agrarian Change, January, 72-86.

Jarsulic, M. (2010) Anatomy of a Financial Crisis: A Real Estate Bubble, Runaway Credit Markets, and Regulatory Failure, New York: Palgrave Macmillan.

Lardner, J. (2009) "Reforming the Rating Agencies: A Solution that Fits the Problem," Demos Briefing Paper, http://www.demos.org/pubs/reforming_ratingagencies.pdf

Sawyer, M. (1982) Macroeconomics in Question: The Keynesian-Monetarist Orthodoxies and the Kaleckian Alternative, Armonk, NY: M.E. Sharpe.

Sheeran, J. (2008) Testimony before the U.S. Senate Committee on Foreign Relations.

Silber, W. (2003) “On the Nature of Trading: Do Speculators Leave Footprints?” Journal of Portfolio Management, 29:4, 64-70. 
Epstein and Pollin

"Regulating Wall Street"

Chapter in forthcoming volume Microeconomics, Macroeconomics and Economic Policy

March 2011

Page 18

Stiglitz, J. (2010), Freefall: America, Free Markets, and the Sinking of the World Economy, paperback edition, New York: Norton.

United Nations Conference on Trade and Development (UNCTAD) (2009) Trade and

Development Report, 2009, Chapter 2, "The Financialization of Commodity Markets," pp. 52-84, Geneva: United Nations. 